\title{
Attitudes toward Environmental Democracy among Urban Communities
}

\author{
Rugayah Hashim ${ }^{1 *}$, Nurul Dalina Mohamad Ristak ${ }^{1}$, Normarliana Laili ${ }^{1}$ \\ ${ }^{1}$ Faculty of Administrative Science \& Policy Studies, Universiti Teknologi MARA, Shah Alam 40450, Selangor, Malaysia
}

\begin{abstract}
With global warming and climate change, the demands for food and water have challenged governments and civil societies. In environmental democracy, governments' transparent processes will see positive citizen-centric developments. Through quantitative research design 384 questionnaires were administered to residents in Johor Bharu, Johor, Malaysia. The findings revealed significant, positive attitude towards environmental democracy. From the three variables, community knowledge is rated the most influential predictor towards environmental democracy. The implication from this study showed that the communities are concerned with environmental issues in the district as participation and volunteerism will ensure the wellbeing of their flora and fauna.
\end{abstract}

(C) 2016. The Authors. Published for AMER ABRA by e-International Publishing House, Ltd., UK. This is an open access article under the CC BY-NC-ND license (http://creativecommons.org/licenses/by-nc-nd/4.0/).

Peer-review under responsibility of AMER (Association of Malaysian Environment-Behaviour Researchers), ABRA (Association of Behavioural Researchers on Asians) and cE-Bs (Centre for Environment-Behaviour Studies), Faculty of Architecture, Planning \& Surveying, Universiti Teknologi MARA, Malaysia.

Keywords: environmental democracy; sustainable development; civil society; attitude

\section{Introduction}

In tandem with the world's population growth, natural resources have dwindled drastically. The demands for food and water from natural resources have challenged governments and civil societies. Aggravating the issues is to this fragile planet is the change in climate and the warming of the globe. With these challenges from nature, how can communities adjust to the scarcity and regenerate for the purpose of sustainability? Through environmental democracy, governments transparently include citizens in decision making with regards to their surrounding whilst maintaining and monitoring the indigenous flora and fauna. With regulations and policies in place, communities, particularly in urban or metro areas can continue to be ensconced in greenery. Hence, the aim of this paper is to present the attitude level on environmental democracy among urban communities. This is a case study involving communities in the district of Johor Bharu, in the state of Johor, Malaysia.

\footnotetext{
* Corresponding author. Tel.: +60133852288

E-mail address: gy@salam.uitm.edu.my
}

2398-4287 @ 2016. The Authors. Published for AMER ABRA by e-International Publishing House, Ltd., UK. This is an open access article under the CC BY-NC-ND license (http://creativecommons.org/licenses/by-nc-nd/4.0/).

Peer-review under responsibility of AMER (Association of Malaysian Environment-Behaviour Researchers), ABRA (Association of Behavioural Researchers on Asians) and cE-Bs (Centre for Environment-Behaviour Studies), Faculty of Architecture, Planning \& Surveying, Universiti Teknologi MARA, Malaysia.

DOI: http://dx.doi.org/10.21834/e-bpj.v1i3.346 


\section{Background of Study}

The Environmental Democracy Index (EDI) tracks countries' progress in enacting national laws to promote transparency, public engagement and access justice in environmental decision-making (EDI, 2015; Martinez, Tazdaït, \& Tovar, 2008). There is evidence that national policymakers are increasingly recognizing the importance of these rights, as an example, the 102 right to Information laws around the world, 42 were enacted in the past 10 years. However, having strong laws does not always guarantee those standards are upheld in practice (Worker, 2015). Environmental democracy is rooted in the idea that meaningful participation by the public is critical to ensuring that land and natural resource decisions adequately and equitably address citizens' interests. Rather than setting a standard for what determines a good outcome, environmental democracy sets a standard for how decisions should be made (Fritsch, 2015; Klinke, 2011). Environmental democracy involves three mutually reinforcing rights that, while independently important, operate best in combination; the ability for people to freely access information on environmental quality and problem, to participate meaningfully in decision making, and to seek enforcement of environmental laws or compensation for damages.

Meanwhile, in Malaysia, the country has been ranked poorly in terms of environmental democratic rights which it coming in $69^{\text {th }}$ of 70 countries surveyed worldwide (Lee, 2015). It showed that Malaysia was given very poor marks on environmental democracy, particularly for transparency and public participation in making environment information available to the public. The index stated that the public only had the right to participate in environmental decision making processes in a limited set of circumstances and that Malaysian law failed to provide for timely enforcement of criminal, civil and administrative decisions concerning the environment (Baber \& Bartlett, 2001; Carbonell, Carbonell, \& Allison, 2015).

\section{Problem Statement}

Making environmental information open and freely accessible can often be the foundation for change. In the United States, governmental agencies such as EPA (Environmental Protection Agency) were created and charged with the responsibility to uphold and enforce environmental laws to ensure that citizens have access to clean water, clean air and to a healthy environment from which to live and thrive (EPIC, 2016). Environmental issues were largely overlooked in opinion surveys until 1965, when they began to garner significant media and political attention (Agnone, 2007; Greenberg, 2005).

As in the developing country like Malaysia, the country has been ranked poorly in terms of environmental democratic rights, coming in $69^{\text {th }}$ of 70 countries surveyed worlwide (Lee, 2015). According to Lee (2015), the report had Malaysia scoring an overall 0.58 out of three points on the US-based World Resources Institutes's Environmental Democracy Index, narrowly beating Haiti. In the report, the index tracks the country's progress in formulating national laws promoting transparency, accountability and public engagement in relation to the environment (Elliott, 2011; Lee, 2015).

The environment and development projects are inextricably linked. Johor Bahru District is one of the committed developing state in Malaysia. With the current development in Johor Bahru, the city has been growing by 5.52 per cent per year over the past 20 years as reported in Johor Structure Plan (Intelligence, 2014). This includes housing projects, industrial projects, infrastructure projects and etc. Therefore, when it comes to the environment, the big problem with Malaysians are that they just do not care enough ("Malaysia jumps to 25 in environmental index," 2012). When there is a landslide or landslip due to the over development of a hill, a lot of people started making noises, calling for a halt to all such developments. This is an eye opener for all. But can we truly expect governments to adhere to such values like transparency, accountability and public participation in relation to the environment if we are not concerned with environmental matter? The communities must know, understand and fight for this right. Thus, this study addresses the attitudes towards environmental democracy among communities in Johor Bahru District.

\section{Research Questions}

The research project was undertaken to answer the following questions:

i) What is the attitude level towards environmental democracy among communities in Johor Bharu? 
ii) What is the influence level between communities' knowledge, participation and support towards environmental democracy?

\section{Research Objectives}

i) To evaluate the attitude level towards environmental democracy among communities in Johor Bharu.

ii) To determine the influence level between communities' knowledge, participation and support towards environmental democracy.

\section{Significance of Study}

The findings from the study are significantly important for stakeholders and policymakers, particularly in ensuring meaningful participation by the public towards caring for that land and natural resource surrounding their homes and premises. Rather than a top-down directing, that is, setting a standard for what determines a good outcome, environmental democracy allows for a bottom-up decision to be made which inherently, addresses citizens' interests.

In citizen-centric planning and decision-making, access rights that are reflected from the Principle 10 of the Rio Declaration on Environment and Development become more prominent (Center for International Environmental Law, 2016). Engaging the communities can help the government to promote transparent, inclusive and accountable environmental decision making by applying good environmental democracy practice. This is part of the Malaysia's national transformation agenda where the practice on sustainable regeneration would invigorate the country's socioeconomic growth (Hashim, Latif, Merican, \& Zamhury, 2015).

\section{Literature Review}

Human beings and the environment are intricately entwined. Culture, tradition and mores are borne from these two variables (Klinke, 2011). From early civilization, man has depended on natural resources to live and procreate. After many centuries of over-dependency on Mother Nature, the damage has been observed through animal extinctions, deforestation, reduced scarce resource such as oil and other mineral deposits, climate change and global warming. Henceforth, when governments, businesses and other agencies make decisions about land and natural resources, they inevitably impact the health, livelihoods and the quality of life of the local communities (Goosen, 2012). So it stands to reason that the public should have a right to be involved in environmental decisionmaking specifically to know what is at stake, to participate in the decision making itself and to have the ability to challenge the decisions that disregard human rights or harm the ecosystems (Fritsch, 2015). These fundamental rights are part of environmental democracy and not all nations provide it to their citizens (CIEL, 2016).

\section{What is environmental democracy?}

Environmental democracy is about government being transparent, accountable, and involving people in decisions that affect the quality of their lives and their environment. In many parts of the world, citizens are still fighting for these basic freedoms and rights that many in the United States take for granted (EPIC, 2016). Indeed, it is likely that a large sector of the American public does not even think about access to environmental democracy. In the United States, governmental agencies, like the EPA (Environmental Protection Agency), were created and charged with the responsibility to uphold and enforce environmental laws to ensure that citizens have access to clean water, clean air and to a healthy environment from which to live and thrive (Agnone, 2007). Other federal and state agencies like the US Fish and Wildlife Services, Bureau of Land Management, National and State Parks, similarly were put in place to oversee and regulate these commonly held resources for the people of the United 
States of America (EPIC, 2016). The Environmental Democracy Index (EDI) tracks countries' progresses in enacting national laws to promote transparency, public engagement and access to justice in environmental decision making (Goosen, 2012; Klinke, 2011).

According to Muigua and Musyimi (2010), environmental democracy may be a recent coinage but what it beliefs are concepts that have been in use all along. The term reflects the increasing recognition that environmental issues must be addressed by all. Or at least a majority of those affected by their outcome, not just by the minority comprising the governments and leading private sector actors (Carbonell et al., 2015). It captures the principle of equal rights for all including the public, community groups, advocates, industrial leaders, workers, governments, academics and other professionals to be involved in environmental governance. It shows the right of all whose daily lives are affected by the quality of the environment to participate in environmental decision making as freely as they do in other public interest matters such as education, health care, finance and government (Baber \& Bartlett, 2001; Goreeba, 2012; Hart, 2013; Mak Arvin \& Lew, 2011). Access to environmental information and justice for all those who choose to participate in such decision-making is integral to the concept of environmental democracy. The generally recognized minimum requirements for existence of environmental democracy is the tripartite of the socalled "access rights" in environmental matters, namely, access to information, participation in decision-making, and access to justice (Muigua \& Musyimi, 2010). These three access rights have the common denominator that they empower individuals to have a meaningful voice in decisions that affect sustainable development (Jacobs, 1999).

The three rights are also intertwined in that achievement and application of each impact on realization of the others. For instance, access to information ensures that all persons who choose to participate in environmental decision making are equipped with the necessary, or at least basic facts about quality of their environment and their legitimate expectation on the same. Being informed of those basic facts about the quality of their environment; citizens can become active participants in identifying and resolving environmental issues at local, national, regional and even global levels. That way the citizens become active participants in environmental governance. The resulting public participation increases vigilance and identification of anomalies that call for engagement of the mainstream justice system in resolution ((Jacobs, 1999; Martinez et al., 2008).

Hence the right of access to justice by all becomes the inevitable way to go if this increased vigilance is to realize real fruits (Bruch, 2000; Fritsch, 2015). It is access to justice that avails the means by which the public ventilate for resolution their reservations on the application of and implementation of environmental laws and policies. Access to justice is also the most potent remedy when access to information or public participation have been wrongly denied or are incomplete in that it guarantees citizens the right to seek judicial review to remedy such denial and/or depravation (Bernauer \& Gampfer, 2015; Brace, Arceneaux, \& Johnson, 2005; Muigua \& Musyimi, 2010).

\section{Importance of environmental democracy}

The rights of citizens and other members of civil society in relation to environmental matters to information, public participation, and access to justice are indispensable if any nation is to foster sustainable development (Damon \& Sterner, 2012; den Uyl \& Driessen, 2015; Human, 2015). The goal of promotion of sustainable development is one that calls for co-operation of the government, private individuals, non-governmental organizations, businesses and others sectors of the society (Mukherjee \& Chakraborty, 2013). The public involvement achieved through this cooperation helps enhance sustainable development efforts in diverse ways. Firstly, public participation allows a wide spectrum of members of the public to express their views regarding environmental issues and conditions confronting them and affecting their immediate domain. The utilization of these views in governmental decision-making on environmental issues results in better implementation of the goals of environmental protection and sustainable development. This is because the resultant decisions are beneficiaries of expanded knowledge base on the nature of environmental problems that are to be met by the decisions (Agnone, 2007; Bruch, 2000).

Secondly, developing environmental laws and policies is a very resource-intensive area. Hence, the public input comes in hardy, especially in developing countries, in supplementing scarce government resources for developing laws and policies. In addition, at the implementation stage, the public vigilance is critical for monitoring, inspection and enforcement of environmental laws and policies by identifying and raising with appropriate authorities, 
environmental threats and violations (Böhmelt, Böker, \& Ward, 2015; Milyo, Richardson, \& Konisky, 2008). Thirdly, public participation can help identify and address environmental problems at an early stage. This helps save reaction-time, energy and the scarce financial resources, at least in the long run. In addition, it improves the reactive and, often, adversarial nature of government action which promises solutions to environmental problems mostly post-facto and only if a there is a physical complainant on board (Muigua \& Musyimi, 2010). Lastly, public involvement in natural resource management also helps improve the credibility, effectiveness and accountability of governmental decision-making processes. This is a result of broad-based consensus for environmental programs that flows from involvement of the public at the infancy stages of the decision making processes (Bruch, 2000).

\section{Environmental democracy in Malaysia}

The EDI (Environmental Democracy Index) assessment was limited to national-level laws, regulations, and practices (EDI, 2015). The national level is the focus of the 2010 UNEP Bali Guidelines, on which the indicators were based (Spence, Kulovesi, Gutiérrez, \& Muñoz, 2008). EDI did not, therefore, assess laws, regulations, or practices enacted at the subnational level. Malaysia is a federal republic with subnational (state) statutes that may affect rights of transparency, participation, and justice beyond federal statutes (Alam, Azam, Abdullah, \& Malik, 2015). As a result, the country index score may not reflect the full extent of access rights accorded to citizens in a federal country (Dittmar \& Ohland, 2012; Mak Arvin \& Lew, 2011).

Nevertheless, literature on the awareness of environmental democray for Malaysia has scarce but relevant stakeholders have been hard at work promoting the need to protect the surroundings through information dissemination. While the law on the environment provides a right to access environmental information on request, government authorities are not obligated to make environmental and public health information available to the public (Thérien \& Bélanger Dumontier, 2009). In e-participation, the public is provided with the right to participate in environmental decision making in only a limited set of circumstances (Hashim et al., 2015). State agencies are not required to account for public comments in environmental decision making. For the Justice pillar, the law fails to provide for the timely enforcement of criminal, civil, and administrative decisions relating to the environment, and the public is not granted broad standing to file environmental claims in court (Fritsch, 2015). By addressing these issues, Malaysia could ensure that environmental information is made available to the public, public comments are incorporated in environmental decision making, and the public is granted the right to file environmental claims in court to address environmental harms (Aziz, Clements, Rayan, \& Sankar, 2013).

Local online newspaper The Star Online (2015) reported that Malaysia has been ranked 69th out of 70 countries surveyed in the World Resources Institute's Environmental Democracy Index (Lee, 2015). Malaysia scored 0.58 , while neighbours Indonesia scored 1.8, Thailand 1.38 and the Philippines 1.35. The global average score is 1.42. According to the report, the index tracks a country's progress in formulating national laws promoting transparency, accountability and public engagement in relation to the environment. Malaysia scored lowly for transparency and public engagement, as government agencies were not obliged to give the public a chance to participate in early stage environment decision-making. Authorities were also not obligated to make environment and public health information available to the public.

The index stated that the public only had the right to participate in environmental decision making processes in a limited set of circumstances and that Malaysian law failed to provide for timely enforcement of criminal, civil and administrative decisions concerning the environment (Lee, 2015). This report is an eye opener for all. The government should learn from the highly ranked countries in the index. For example, the top 10 countries in the index allow the public to participate in major, national environmental decisions. This includes infrastructure projects, forest management planning and pollution permitting amongst others. Malaysia is doing well as all the information on all environmental laws and policies are made proactively available. Laws relating to protected areas and mining provide opportunities for the public to participate in decision making concerning the environment. 


\section{Research Methodology}

In order to achieve the objectives of this study, the research design used were a cross-sectional survey and quantitative method or also known as descriptive method. It was set out to seek accurate and adequate description or characteristic of the research. Cross-sectional survey was used because the data collection can be collected in a sufficient time given to answer all of the research questions (Sekaran \& Bougie, 2010). The study can be done in which the data were obtained once, maybe a period of days, weeks or months or known as one-shot studies. The data were used to find the answer for research questions. Quantitative method is a research method that relies on the primary data from questionnaires and focuses more on the collectionand analysis of numerical data. The secondary data will be collected from all the information obtained such as journals, articles, books, news and through websites on the Internet. As the objectives require determining the influence level of the variables (see Figure 1), the unit of analysis are the residents from the development areas or communities in Johor Bahru District (see Table 1). Therefore, 384 questionnaires were administered to the residents and the response rate was $100 \%$.

Table 1. Determination of sample size.

\begin{tabular}{lcc}
\hline \multicolumn{1}{c}{ Developmental area/Community } & Population & Sample size \\
\hline Bandar Nusajaya & 134,759 & 64 \\
Gelang Patah & 46,469 & 64 \\
Lima Kedai & 45,472 & 64 \\
Skudai & 54,308 & 64 \\
Bandar Baru Uda & 73,647 & 64 \\
Teluk Danga & $55,316 \quad$ Total & 64 \\
& & 384 \\
\hline
\end{tabular}

Nevertheless, the conceptual framework for the variables are shown in Figure 1.

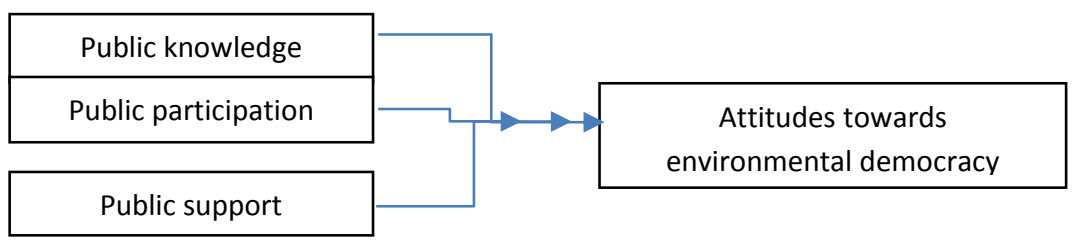

Fig. 1. Conceptual Framework on Environmental Democracy

\section{Findings}

Table 2 shows the demographic profiles of the respondents starting with gender where $41.9 \%$ are male and $58.1 \%$ are female. Majority of the respondents were in the age range of $21-30$ years $(56.8 \%)$. Those in the age of below 20 years were $16.1 \%, 14.8 \%$ were in the age range of $31-40$ years and only $12.2 \%$ were 41 years old and above. Highest education reported by respondents showed $42.2 \%$ had Bachelor degree, $31.5 \%$ had certificate of SPM, $17.7 \%$ had diploma or undergone foundation, $4.9 \%$ had a Master's degree, $3.1 \%$ had a certificate of STPM and only $0.5 \%$ had $\mathrm{PhD}$. A total of $52.6 \%$ respondents were unmarried, $46.9 \%$ were married and only $0.5 \%$ was divorced. Majority of respondents were reported working (62.0\%) while $29.1 \%$ were students and only $8.9 \%$ were unemployed 
Table 2. Demographic profiles of respondents

\begin{tabular}{llll}
\hline Demography & Factor & Frequency & $\%$ \\
\hline Gender & Male & 161 & 41.9 \\
Age & Female & 223 & 58.1 \\
& $<20$ years & 62 & 16.1 \\
& $21-30$ & 218 & 56.8 \\
\multirow{4}{*}{ Education } & $31-40$ & 57 & 14.8 \\
& $>40$ years & 47 & 12.2 \\
& STPM & 12 & 3.1 \\
& SPM & 121 & 31.5 \\
& Diploma/Foundation & 68 & 17.7 \\
& Undergraduate & 162 & 42.2 \\
& Master & 19 & 4.9 \\
Work Status & PhD & 2 & 0.5 \\
& Student & 112 & 29.1 \\
& Working & 238 & 62.0 \\
\hline
\end{tabular}

On to the first research objective which is the communities' attitude level towards environmental democracy in Johor Bharu, the analysis showed a significant attitude. The mean scores are shown in Table 3. All the six items showed mean scores close to the maximum scale of five. The last item, "I support environmental democracy" has the highest mean of 4.30 .

Table 3. Table 2. Demographic profiles of respondents

\begin{tabular}{ll}
\hline \multicolumn{1}{c}{ Item } & Mean \\
\hline I am concern with environmental issues in my district. & 4.01 \\
I pay attention to environmental news within my area. & 4.16 \\
I am aware on environmental information within my area. & 4.15 \\
I practice environmental democracy to ensure the environment & 4.01 \\
within my area is safe. & \\
I am aware that I can participate in environmental democracy. & 4.14 \\
I support environmental democracy. & 4.30 \\
\hline
\end{tabular}

For the second objective which is to determine the influence level between communities' knowledge, participation and support towards environmental democracy, the hypothesis proved that there is a significant influence level $(p<0.5)$. Table 4 provides the correlation coefficient between communities' knowledge, participation and support towards environmental democracy among communities in the district of Johor Bharu. The interpretation and discussion on this finding will be elucidated in the next section.

Table 4. Correlation coefficient between communities' attitudes toward environmental democracy

\begin{tabular}{|c|c|c|}
\hline & & $\begin{array}{c}\text { Attitude towards } \\
\text { ED }\end{array}$ \\
\hline \multirow{3}{*}{$\begin{array}{c}\text { Communities' } \\
\text { knowledge }\end{array}$} & Pearson Correlation & 0.521 \\
\hline & Sig. (2-tailed) & 0.000 \\
\hline & $\mathrm{N}$ & 384 \\
\hline
\end{tabular}

\section{Implications of Research Findings}

The implications from the findings revealed that there is a significant level of attitude towards environmental democracy among the communities with positive relationships to community knowledge, participation and support. From the three variables, community knowledge is rated as the most influential predictor towards environmental democracy. Moreover, the implication from this study indicated that the communities are concerned with 
environmental issues in the district, hence, participation and ensuring the wellbeing of the environment is positively correlated to environmental democracy. Nonetheless, for a developing nation like Malaysia, continuous efforts in informing the public on environmental issues are crucial. Though political will is of utmost importance, public participation should be voluntary, that is, don't wait for the government, private sector of NGOs (Non-governmental organizations) to start the ball rolling. Education plays an important role too as articles and readings available on the world wide web would provide current information on preserving the environment and our natural heritage. As such, the value of information disseminated should be fast and accurate as economic agents make important decisions under conditions of uncertainty (Quiggin, 2016). What this means is that the cascading on relevant information to communities on environmental protection should be updated regularly. This is where local authorities for the Johor Bharu district should ensure that their web portal is monitored for current content are uploaded.

Anyhow, support from the communities through awareness programs on environmental and ecological preservations are crucial. Promotion activities on these issues can be bundled with preparedness for annual flooding, for example. In times of flooding which regularly occurs at this district, fatalities will be reduced, yet the surrounding areas are enhanced and not annihilated. Upsetting the ecosystem will bring more harm, thus, the communities' civic consciousness should be augmented. Furthermore, environmental democracy attitude is important as human beings should continue to be responsible for the surroundings in view of climate change and global warming. Harming the environment will upset the ecosystem and communities, with inevitable impacts to health, livelihood and quality of life.

\section{Conclusion}

As a conclusion, the study on attitude towards environmental democracy among communities was done in response to the alarming issues that concern over Mother Earth. When governments, businesses and others make decisions about land and natural resources, they inevitably impact the health, livelihoods and quality of life of local communities. So it stands to reason that the communities should have a right to be involved in environmental decision making specifically to know what is at stake, to participate in the decision itself and to have the ability to challenge decisions that disregard human rights or harm the ecosystems. The findings have revealed that there is a significant level of attitude towards environmental democracy among communities in Johor Bahru District and the attitude has significant relationship to communities' knowledge, participation and support. From the results obtained, most of the hypotheses were accepted and from this study, it found that communities' knowledge has the most influential predictor to the attitude towards environmental democracy in Johor Bahru District. Apart from that, education level was found not significant to the relationship to affect the association of the independent and dependent variables. Thus, communities' knowledge, communities' participation and communities' support were all contributes to a positive significant level of attitude towards environmental democracy among communities in Johor Bahru District.

\section{Acknowledgements}

The researchers would like to thank the residents in Johor Bharu, Johor for their cooperation towards this study, the Ministry of Higher Education, Malaysia for the financial support in the form of the Research Acculturation Grant Scheme (RAGS 124/2013) and, the Dean, Faculty of Administrative Science \& Policy Studies, Universiti Teknologi MARA, Shah Alam, Selangor.

\section{References}

Agnone, J. (2007). Amplifying Public Opinion: The Policy Impact of the U.S. Environmental Movement. Social Forces, 85(4), $1593-1620$.

Alam, A., Azam, M., Abdullah, A. B., \& Malik, I. A. (2015). Environmental quality indicators and financial development in Malaysia: unity in 
diversity. Environmental science and pollution research international, 22(11), 8392-8404. doi: 10.1007/s11356-014-3982-5

Aziz, S. A., Clements, G. R., Rayan, D. M., \& Sankar, P. (2013). Why conservationists should be concerned about natural resource legislation affecting indigenous peoples' rights: lessons from Peninsular Malaysia. Biodiversity and conservation, 22(3), 639-656. doi: 10.1007/s10531-013$0432-5$

Baber, W. F., \& Bartlett, R. W. (2001). Toward environmental democracy: rationality, reason, and deliberation. The Kansas journal of law \& public policy, 11(1), 35 .

Bernauer, T., \& Gampfer, R. (2015). How robust is public support for unilateral climate policy? Environmental Science and Policy, 54, 316-330. doi: 10.1016/j.envsci.2015.07.010

Böhmelt, T., Böker, M., \& Ward, H. (2015). Democratic inclusiveness, climate policy outputs, and climate policy outcomes. Democratization. doi: 10.1080/13510347.2015.1094059

Brace, P., Arceneaux, K., \& Johnson, M. (2005). Public Opinion and Dynamic Representation in the American States: The Case of Environmental Attitudes. Social science quarterly, 86(1), 87-108.

Bruch, C. (2000). Regional opportunities for improving environmental governance through access information, public participation and access to justice.

Carbonell, J. R., Carbonell, J. R., \& Allison, J. E. (2015). Democracy and state environmental commitment to international environmental treaties. International environmental agreements : politics, law and economics, 15(2), 79-104. doi: 10.1007/s10784-013-9213-6

CIEL. (2016). Enviro Democracy \& Access Rights. Retrieved January 26, 2016, from http://www.ciel.org/issue/environmental-democracyaccess-rights/

Damon, M., \& Sterner, T. (2012). Policy Instruments for Sustainable Development at Rio +20. The Journal of Environment \& Development, 21(2), 143-151. doi: 10.1177/1070496512444735

den Uyl, R. M., \& Driessen, P. P. J. (2015). Evaluating governance for sustainable development - Insights from experiences in the Dutch fen landscape. Journal of Environmental Management, 163, 186-203. doi: 10.1016/j.jenvman.2015.08.022

Dittmar, H., \& Ohland, G. (2012). The new transit town: Best practices in transit-oriented development: Island Press.

EDI. (2015). Environmental Democracy Index-Malaysia. 2016, from http://www.environmentaldemocracyindex.org/country/MYS

Elliott, L. (2011). ASEAN and environmental governance: Rethinking networked regionalism in Southeast Asia. Paper presented at the Procedia Social and Behavioral Sciences.

EPIC. (2016). Protecting Environmental Democracy. Retrieved January 26, 2016, from http://www.wildcalifornia.org/actionissues/environmental-democracy/

Fritsch, M. (2015). Democracy, Climate Change, and Environmental Justice. Mosaic : a Journal for the Interdisciplinary Study of Literature, 48(3), $27-45$.

Goosen, M. F. A. (2012). Environmental management and sustainable development. Paper presented at the Procedia Engineering.

Goreeba, A. (2012). Environmental democracy? Does anyone really care?

Greenberg, M. (2005). Environmental Protection as a US National Government Priority: Analysis of Six Annual Public Opinion Surveys, $1999-$ 2004. Journal of environmental planning and management, 48(5), 733-746.

Hart, R. A. (2013). Children's participation: The theory and practice of involving young citizens in community development and environmental care. New York: Routledge.

Hashim, R., Latif, Z. A., Merican, F. M., \& Zamhury, N. (2015). The Praxis of Langkawi's Sustainable Regeneration Strategy through Eco-tourism. Procedia - Social and Behavioral Sciences, 170, 49-57. doi: http://dx.doi.org/10.1016/j.sbspro.2015.01.014

Human, H. (2015). Democratising world heritage: The policies and practices of community involvement in Turkey. Journal of Social Archaeology, 15(2), 160-183. doi: 10.1177/1469605314566557

Intelligence, W. M. (2014). KLD - Nusajaya Mixed-use Development - Johor - Construction Project Profile. London: Progressive Media Group. 
Jacobs, M. (1999). Environmental Democracy. The Political quarterly (London. 1930), 70(s1), 105-116. doi: 10.1111/1467-923X.70.s1.11

Klinke, A. (2011). Deliberative democratization across borders: Participation and deliberation in regional environmental governance. Paper presented at the Procedia - Social and Behavioral Sciences.

Lee, P. (2015). Malaysia ranked near botton on the class by environmental democracy watchdog, The Star. Retrieved from http://www.thestar.com.my/news/nation/2015/05/20/malaysia-low-environmental-ranking/

Mak Arvin, B., \& Lew, B. (2011). Does democracy affect environmental quality in developing countries? Applied economics, 43(9), 1151-1160. doi: $10.1080 / 00036840802600277$

Malaysia jumps to 25 in environmental index. (2012). New Straits times.

Martinez, E., Tazdaït, T., \& Tovar, E. (2008). Participative democracy and local environmental issues. Ecological Economics, 68(1-2), 68-79. doi: http://dx.doi.org/10.1016/j.ecolecon.2008.01.025

Milyo, J., Richardson, L. E., \& Konisky, D. M. (2008). Environmental Policy Attitudes: Issues, Geographical Scale, and Political Trust. Social science quarterly, 89(5), 1066-1085.

Muigua, K., \& Musyimi, P. (2010). Enhancing environmental democracy in Kenya.

Mukherjee, S., \& Chakraborty, D. (2013). Is environmental sustainability influenced by socioeconomic and sociopolitical factors? cross-country empirical evidence. Sustainable Development, 21(6), 353-371. doi: 10.1002/sd.502

Quiggin, J. (2016). The value of information and the value of awareness. Theory and Decision, 80(2), 167-185.

Sekaran, U., \& Bougie, R. (2010). Research Methods for Business: A Skill-Building Approach. London, UK: Wiley.

Spence, C., Kulovesi, K., Gutiérrez, M., \& Muñoz, M. (2008). Great Expectations: Understanding Bali and the Climate Change Negotiations Process. Review of European Community \& international environmental law, 17(2), 142-153. doi: 10.1111/j.1467-9388.2008.00594.x

Thérien, J.-P., \& Bélanger Dumontier, M. (2009). The United Nations and Global Democracy: From Discourse to Deeds. Cooperation and Conflict, 44(4), 355-377. doi: 10.1177/0010836709344447 